\title{
In situ tests for water quality assessment: a case study in Pampean rivers
}

\author{
Manuel A.S. Graça ${ }^{\mathrm{a}, *}$, Alberto Rodrígues-Capítulo ${ }^{\mathrm{b}}$, Carolina Ocón ${ }^{\mathrm{b}}$, \\ Nora Gómez \\ a Departamento de Zoologia, Universidade de Coimbra, 3004-517 Coimbra, Portugal \\ b Instituto de Limnología "dr. Raúl A. Ringuelet" (ILPLA) CC 712, CP 1900 La Plata, Argentina
}

Received 14 May 2001; accepted 19 February 2002

\begin{abstract}
Two invertebrate species (Hyalella curvispina and Palaemonetes argentinus) and one macrophyte (Egeria densa) from a naturally high nutrient content system (Pampean rivers of La Plata, Argentina) were evaluated for their potential use in situ assays aiming to assess changes in water quality. Invertebrates were individually placed in cylindrical chambers in polluted sections of rivers and in reference upstream sites. Mortality after $48 \mathrm{~h}$ was high in polluted and reduced in control sites. Mortality was also higher in situ assays than in laboratory static tests. Standard sections of the macrophyte were also deployed at the reference and control sites. Growth (7 days) in terms of mass increment (but not in length) was consistently reduced in polluted sites. Results of benthic invertebrate and periphitic algae surveys were consistent with the in situ tests: pollution resulted in a decrease in the number of taxa, taxa replacement and in changes in the value of the biotic indices İndice Biótico PAMPeano and Índice de Diatomeas Pampeano, indicating deterioration of water quality. In situ assays have a high potential as environmental tools in integrated approaches of bioassessment programs. (C) 2002 Elsevier Science Ltd. All rights reserved.
\end{abstract}

Keywords: Biomonitoring; Ecotoxicology; In situ tests; Biotic indices; Pampas; Hyalella; Palaemonetes; Egeria

\section{Introduction}

Pollution has the potential to affect the biological integrity of aquatic systems, decreases the quality of waters and may directly affect human health. The effects of anthropogenic disturbances in the receiving systems can be assessed by measuring changes in community structural parameters including biodiversity indicators (diversity, species and taxonomic richness), biotic indices, community structure (multivariate methods) or changes in functional parameters such as energy allocated to growth $[1,2]$.

\footnotetext{
*Corresponding author. Tel.: +351-239-828071; fax: +351239-826798.

E-mail address: mgraca@ci.uc.pt (M.A.S. Graça).
}

Toxicity tests are used to estimate safe concentrations of toxic substances and effluents to be discharged in the receiving waters and the potential impacts of such discharges [3]. Traditionally, toxicity tests use single standard species under standard laboratory conditions [3]. Besides the usefulness of such a procedure, it is difficult to extrapolate laboratory results to site-specific conditions. Moreover, many standard tests use species with no ecological relevance to systems under study. The relationship between the results of standard laboratory tests and field responses is, therefore, unclear. Some authors have advocated the use of multispecies tests in mesocosms e.g. $[4,5]$ and field experiments, including in situ assays, to add some more realism to the effects of pollution in the receiving systems e.g. [6-9].

Here, we assess the use of caged native species to determine the impact of pollution discharges on the 
biological quality of streams. The research was carried out in several streams and rivers of La Plata area, Argentina, which are naturally rich in nutrients, suspended solids and humic compounds. The sites were selected because of the available background of biological and chemical information. As testing organisms, we used the amphipod Hyalella curvispina Shoemaker, the shrimp Palaemonetes argentinus Nobili and the aquatic macrophyte Egeria densa Planch.

The invertebrates were selected because they were widespread and abundant in unpolluted sites during all year, they were easy to collect, manipulate and maintain under laboratory conditions and because of the availability of data regarding their ecology [10-12]. Previous experiments also showed that these invertebrates were sensitive to pollution [13].

The aquatic macrophyte $E$. densa was selected as a testing species because it is also widespread, locally abundant, native to the Pampean systems and potentially sensitive, as judged by its disappearance from polluted locations. The plant is also robust, easy to manipulate and the Northern Hemisphere-related species Elodea canadensis Michx. has been shown to be sensitive to industrial effluents (Ferreira and Graça, unpublished).

\section{Materials and methods}

The streams selected for the experiments are located at the Northeast of the Buenos Aires province, Argentina. In general, we selected pairs of sites with upstream-unpolluted conditions and downstream sites polluted by the discharge of sewage or industrial effluents (Fig. 1). The test sites were located at the

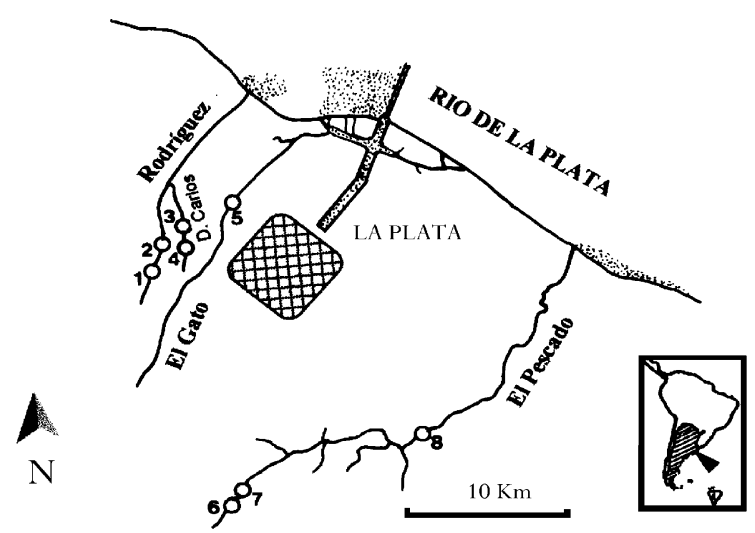

Fig. 1. Location of the stream sites (circles) in three catchments of La Plata: Rodríguez reference (1); Rodríguez impacted (2); Don Carlos impacted (3); Don Carlos reference (4); El Gato impacted (5); El Pescado reference 1 (6); El Pescado impacted (7); El Pescado reference 2 (8). rivers: (1) "El Pescado", $300 \mathrm{~m}$ above and $50 \mathrm{~m}$ below an industrial output and, additionally, at a downstream recovered site, $18 \mathrm{~km}$ apart (respectively, sites 6,7 and 8); (2) "Rodríguez", above and below an abattoir, $5 \mathrm{~km}$ apart (respectively, sites 1 and 2); (3) "Don Carlos", above and below a textile effluent output, $1 \mathrm{~km}$ apart (respectively, sites 3 and 4); (4) "El Gato", a river receiving a urban sewage waters (site 5). In general, these streams and rivers run Northeastern in a flat area. They are short (maximum length $35 \mathrm{~km}$ ) and from source to mouth they generally flow from pastureland areas to agricultural fields, industry and urban areas. The sediments are strongly calcareous, and the waters have a high content of suspended solids (up to $354 \mathrm{mg} / \mathrm{L}$ ) and low transparency $(<40 \mathrm{~cm})$ [14]. Riparian vegetation varies from exclusively herbaceous plants to spaced/ abundant deciduous and evergreen trees. In the absence of pollution and riparian trees, hydrophytes are abundant and represented by a variety of species, including Ceratophyllum demersum L., Myriophyllum elatinoides Gaud., Potamogeton striatus Ruiz et Pavon, Potamogetum spp., Chara sp., Lemna gibba L., Spirodella intermedia W Koch [14]. Previous studies at the same polluted sites revealed that the discharge of effluents resulted in high conductivity, nitrites, nitrates and phosphates and low oxygen content [15].

We ran an acute test comparing survival of caged invertebrates implanted in reference and polluted sites and a chronic test measuring the growth of an aquatic plant. The invertebrates were the amphipod $H$. curvispina and the shrimp $P$. argentinus whereas the aquatic plant was the macrophyte $E$. densa.

We deployed invertebrates in chambers made of PCV cylinders $(10 \mathrm{~cm}$ length, $6 \mathrm{~cm}$ diameter, $0.3 \mathrm{~mm}$ mesh size nets at both ends). Each cylinder consisted of two sections, one slotted inside the other (Fig. 2). Individuals of $H$. curvispina and $P$. argentinus were collected from El Pescado river (site 8) in December 2000. The site was considered as unpolluted, based on the invertebrate taxa present, dissolved oxygen and conductivity values (see Section 3).

The amphipods were collected from submerged vegetation in shallow areas with a kitchen sieve. We

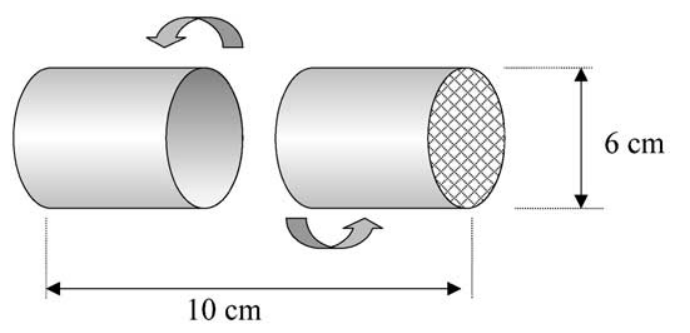

Fig. 2. Chambers used for implanting invertebrates in the streams. 
selected large males (7-9 $\mathrm{mm}$ range length, measured from the tip of the head to the end of the telson) obtained from pre-copula pairs. Only males of amphipods were used to avoid physiological differences in sex, which could result in differential responses to environmental stress. Shrimps were collected with a hand net and the size of the specimens used in the tests ranged from 29 to $35 \mathrm{~mm}$ in length. The numbers of invertebrates deployed in the testing chambers were 5 and 3, respectively, for $H$. curvispina and $P$. argentinus. At each site, four testing chambers for each species were placed in the streambed in a shallow area. After $48 \mathrm{~h}$, the chambers were retrieved and number of surviving animals counted. Data from individual chambers was pooled and comparison between control and potentially impacted sites was made by $\chi^{2}$ [16]. In some occasions the number of amphipods inside the chambers resulted to be 4 (dead or alive) instead of 5 . This could be the result of: (a) counting mistakes when allocating the amphipods to the chambers, (b) evasion through the net or (c) consumption by other amphipods after being dead. In this situation the initial sample size was the total number of invertebrates found inside the chambers.

To compare the results of field and laboratory tests, sets of 5 amphipods and 3 shrimps (3 replicates each) were also deployed in $0.5 \mathrm{~L}$ plastic jars under laboratory conditions. The jars contained either water from the reference site where the invertebrates were collected (El Pescado) or from the polluted Don Carlos stream. Comparison of survivorship between (1) clean and polluted water and (2) field and laboratory results, (Don Carlos, polluted water) were made by $\chi^{2}$ [16].

Plants were collected from the upper sections of the Rodríguez stream, transported to the laboratory where terminal sections of exactly $19 \mathrm{~cm}$ were cut, carefully wrapped with filter paper for $1 \mathrm{~min}$ and weighed to the nearest $0.01 \mathrm{~g}$. We selected sections with no roots or lateral ramifications. Two plant sections were placed inside $20 \times 15 \mathrm{~cm}^{2}$ plastic bags, $5 \mathrm{~mm}$ mesh size. Ten bags were implanted in the stream sites (except in "El Gato" because of the extreme pollution).

After 1 week of deployment, the bags were collected, transported to the laboratory, and the biological status of the plants evaluated (i.e. presence of necrosed tissues, leaf losses, atypical leaf coloration). The specimens were then measured, weighed as before and the number and total length of roots recorded. Results were expressed in terms of $\%$ mass or length increase. We compared upstream reference sites and downstream impacted sites by Mann-Whitney $U$ tests.

From each stream site we took 3 replicate benthic invertebrate samples with an Ekman grab $\left(100 \mathrm{~cm}^{2}\right)$. Samples were collected in muddy bottom sections. Additionally, qualitative samples were also taken from macrophytes with a hand net $(30 \mathrm{~cm}$ diameter and $0.5 \mathrm{~mm}$ mesh). Samples were fixed in $5 \%$ of formalde- hyde in the field. The invertebrates were sorted in the laboratory, identified to species, genus or family levels. Invertebrate data was used to determine water quality according to the biotic index "Índice Biótico PAMPeano" (IBPAMP) [15]. The values of the IBPAMP biotic index rank between 13 (unpolluted) and 1 (very heavily polluted).

In each sampling site, a number of 10 sub-samples of $1 \mathrm{~cm}^{2}$ were collected by pippeting $[17,18]$ a superficial layer of $5-10 \mathrm{~mm}$ of the sediment. The organic matter fraction was removed with acid and clean diatoms were mounted in Naphrax. In each sample a total of 300 valves were examined under a magnification $1250 \times$ to determine the relative abundance of each taxon. Diatom data was also used to assess water quality according with the Índice de Diatomeas Pampeano (IDP) [19]. The values of the index range from 0 (good water quality conditions) to 4 (very low water quality).

Dissolved oxygen, $\mathrm{pH}$, conductivity and temperature were measured in the field with portable meters (Oxymeter 600-ESD, pHtester 2 waterproof ColePalmer, Hanna HI8633 conductivity meter, respectively). Water samples were also collected and transported to the laboratory (at $4{ }^{\circ} \mathrm{C}$ ) for measurements of biochemical oxygen demand $\left(\mathrm{BOD}_{5}\right)$, chemical oxygen demand (COD), nitrate $\left(\mathrm{NO}_{3}\right)$, nitrite $\left(\mathrm{NO}_{2}\right)$, ammonium $\left(\mathrm{NH}_{4}\right)$, soluble reactive phosphorous (SRP) and hardness, according to Strickland and Parsons [20] and Mackereth et al. [21]. Each environmental parameter was measured at beginning and at the end of the experiment

\section{Results}

The Pampean rivers studied had natural conditions characterized by a low oxygen and high nutrient concentration, and slightly alkaline (Table 1).

Survivorship of $H$. curvispina and $P$. argentinus was significantly lower in the impacted areas when compared to reference, upstream sections $\left(\chi^{2}=11.45-38.00\right.$; d.f. $=1 ; \quad P<0.001 ;$ Table 1). Survivorship of both invertebrates under laboratory conditions was high, ranging from $100 \%$ for $P$. argentinus (polluted and unpolluted water) to $70 \%$ for $H$. curvispina (polluted water). Therefore, survivorship of specimens reared in clean and polluted waters was not statistically different under laboratory conditions $\left(\chi^{2}=2.45\right.$; d.f. $=1 ; P>$ 0.05 ; Table 2). Survivorship of both $P$. argentinus and $H$. curvispina in polluted waters was significantly lower in in situ experiments than in laboratory static tests using stream water $\left(\chi^{2}=15.00-24.14\right.$; d.f. $\left.=1 ; P<0.001\right)$.

Specimens of the macrophyte $E$. densa implanted in the rivers grew in terms of mass and length in all but one site (Fig. 3). Mass increment reached $51 \%$ in 1 week, whereas increment in length reached $24 \%$. Mass increase 
Table 1

Percent survival (mean \pm SE) of Hyalella curvispina $(n=5)$ and Palaemonetes argentinus $(n=3)$ in chambers incubated at the reference and polluted sites in several rivers of La Pampa

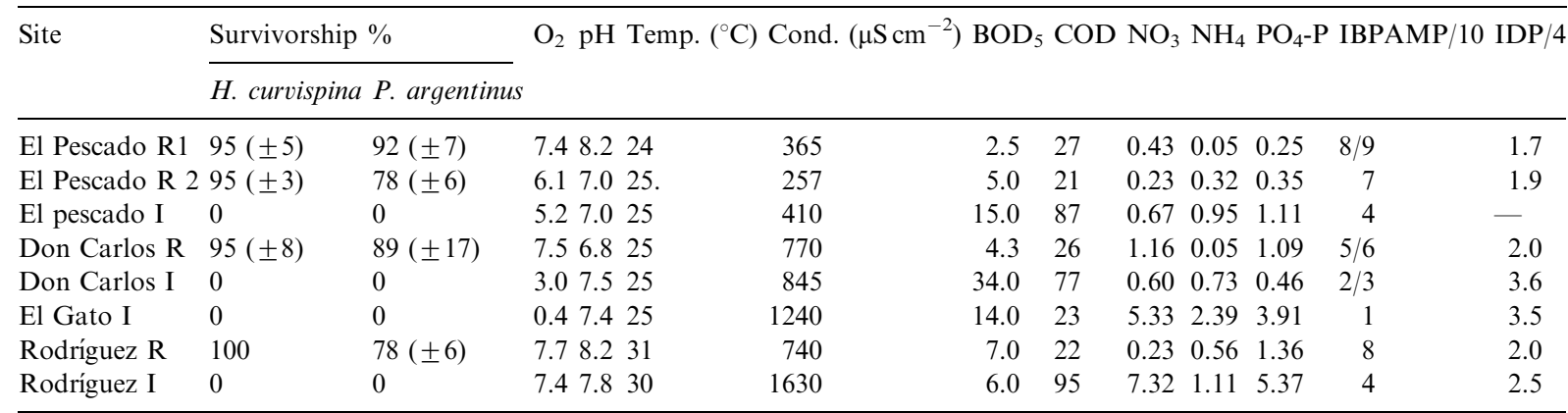

$\mathrm{R}=$ reference, $\mathrm{I}=$ impacted. The units for $\mathrm{BOD}_{5}, \mathrm{COD}, \mathrm{NO}_{3}, \mathrm{NH}_{4}, \mathrm{PO}_{4}-\mathrm{P}$ and $\mathrm{O}_{2}$ are $\mathrm{mg} / \mathrm{L}^{-1}$.

Table 2

Survivorship of Hyalella curvispina and Palaemonetes argentinus in reference (El Pescado) and polluted (Don Carlos) water in situ tests and under laboratory conditions

\begin{tabular}{lcclll}
\hline \multirow{2}{*}{ Species } & \multicolumn{2}{c}{ Laboratory test } & & \multicolumn{2}{l}{ In situ test } \\
\cline { 2 - 3 } \cline { 5 - 6 } \cline { 5 - 6 } & Reference & Polluted & & Reference & Polluted \\
\hline H. curvispina & 87 & 70 & & 100 & 0 \\
P. argentinus & 100 & 100 & & 78 & 0 \\
\hline
\end{tabular}
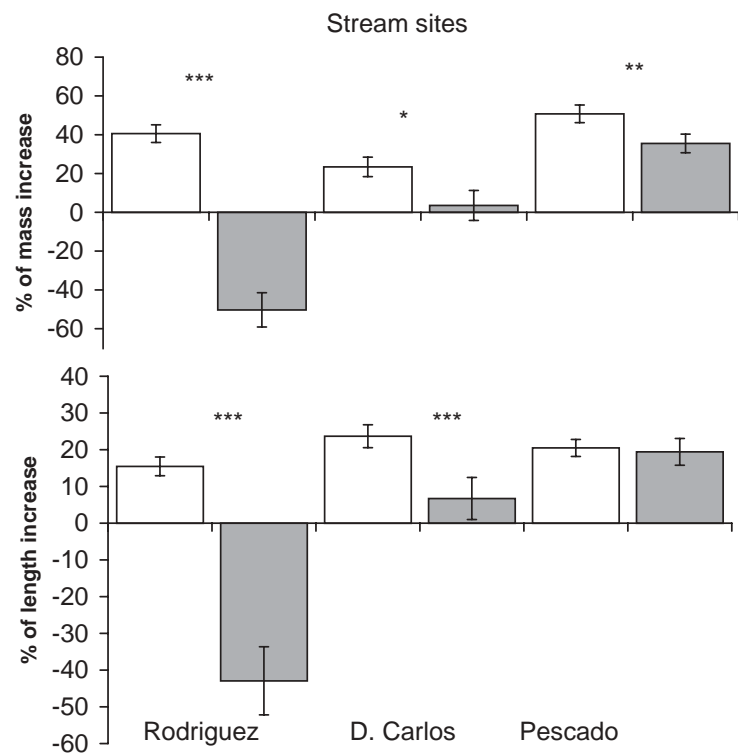

Fig. 3. Growth (in terms of mass and length) of $E$. densa exposed to reference (white bars) and impacted (grey bars) sites. Mean \pm SE, $n=16$ (except Gorina, $n=8$ ). $P<0.05\left(^{*}\right), P<0.01$ $(* *), P<0.001(* * *)$. was significantly lower at impacted than at the reference sites $(Z>2.26, n=32, P<0.05)$. Equivalent differences in length were significant only at Rodríguez stream $(Z=3.93, n=16, P<0.001$; Fig. 3 ). The development of branches occurred only in one of the rivers, regardless of the pollution status (Table 3). The development of roots also occurred only in two of the rivers, regarding the pollution status (Table 3). Finally, in two of the impacted sites plants lost their integrity with detachment of leaves (Table 3 ).

The reference sites had, in general, a relatively high diverse community of invertebrates, whereas in the most heavily polluted sites (e.g. Don Carlos and El Gato) invertebrates were seldom seen (Table 4). The characteristic and dominated benthic diatoms (relative abundance $>5 \%$ ) differed between the reference and polluted sites, with high diversity in reference sites (Table 4).

In the reference sites, the biotic index IBPAMP (macroinvertebrates) scored 8 to 9 indicating the possibility of "light pollution" conditions (Table 1). The IDP biotic index (diatoms) scored 1.7-2, indicating a probable moderate pollution-eutrophication in the same sites. Comparatively, in the impacted sites, the scores decreased to values of $1-4$ in the case of IBPAMP and increased to 2.5-3.6 in the case of IDP. Those scores indicated that the water quality at the impacted sites (El Gato, Rodríguez, Don Carlos and Pescado) was bad and the river sections were heavily or very heavily polluted (Table 1; Fig. 4).

\section{Discussion}

The values for dissolved oxygen were very low at some reference sites (e.g. El Gato), which were consistent with previous records [22]. The reference sites do not receive 
Table 3

Summary of changes in experimental plants exposed to impacted and reference sites $(n=20)$

\begin{tabular}{|c|c|c|c|c|c|}
\hline & $\begin{array}{l}\text { Plants with branch } \\
\text { development }\end{array}$ & $\begin{array}{l}\text { Mean branch } \\
\text { length }(\mathrm{cm})\end{array}$ & $\begin{array}{l}\text { Plants with root } \\
\text { development }\end{array}$ & $\begin{array}{l}\text { Mean root length } \\
(\mathrm{cm})\end{array}$ & Plant integrity \\
\hline El Pescado reference & 1 & 3 & 0 & - & + \\
\hline El pescado impacted & 2 & 3.7 & 6 & 3.4 & + \\
\hline Don Carlos reference & 0 & - & 0 & - & + \\
\hline Don Carlos impacted & 0 & - & 0 & - & - \\
\hline Rodríguez reference & 0 & & 2 & 2.5 & + \\
\hline Rodríguez impacted & 0 & - & 0 & - & - \\
\hline
\end{tabular}

Plants with detached leaves, stem fragmentation or necrotic tissues were classified as having low ( - ) integrity.

Table 4

Common algal and macroinvertebrate taxa at reference and polluted sites at 4 Panpean streams

\begin{tabular}{|c|c|c|}
\hline & Algae & Macroinvertebrates \\
\hline Reference & $\begin{array}{l}\text { Gompphonema truncatum Ehrenberg } \\
\text { G. clavatum Ehrenberg } \\
\text { Melosira varians Agardh } \\
\text { Cymbella sileciaca Bleisch } \\
\text { Pinnularia gibba Ehrenberg var linerais Hustedt } \\
\text { Nitzschia filiformis (W.M. Smith) Van Heurk } \\
\text { N. hungarica } \text { Grunow } \\
\text { N. frustulum Kützing } \\
\text { N. angustata } \text { Grunow } \\
\text { Navicula erifuga Lange-Bertalot } \\
\text { N. radiosa Kützing } \\
\text { Diploneis ovalis } \text { (Hilse) Cleve } \\
\text { Pinnularia. Subcapitata } \text { Gregory }\end{array}$ & $\begin{array}{l}\text { Nematoda } \\
\text { Cnidaria } \\
\text { Platyhelminta } \\
\text { Naididae } \\
\text { Hirudinea } \\
\text { Bivalvia (Diplodon delodontus delodontus (Lamark)) } \\
\text { Ampullaridae (Pomacea canaliculata (Lamark)) } \\
\text { Ephemeroptera (Baetis sp. and Caenis sp.) } \\
\text { Odonata Coenagrionidae } \\
\text { Odonata Aeshnidae (Aeshna bonariensis Rambur) } \\
\text { Belostomatidae (Belostoma oxyurum Dufour) } \\
\text { Coleoptera (Hydrophilidae) } \\
\text { Diptera (Chironomidae) } \\
\text { Amphipoda (Hyalella curvispina) } \\
\text { Palaemonidae (Palaemonetes argentinus and Macrobrachium } \\
\text { borelli Nobili) } \\
\text { Ostracoda }\end{array}$ \\
\hline Polluted & $\begin{array}{l}\text { Gomphonema parvulum Kützing } \\
\text { Navicula pupula Kützing } \\
\text { Navicula cryptocephala Kützing } \\
\text { Pinnularia gibba } \text { Ehrenberg } \\
\text { Nitzschia umbonata } \text { (Ehrenberg) Lange-Bertalot } \\
\text { N. palea (Kützing) W. Smith }\end{array}$ & $\begin{array}{l}\text { Chironomidae } \\
\text { Zygoptera } \\
\text { Ostracoda } \\
\text { Belostoma sp. }\end{array}$ \\
\hline
\end{tabular}

industrial or urban effluents although some nutrient run-off from agricultural activities cannot be ruled out. The low value of dissolved oxygen can be attributed to the high organic matter content, coupled with high summer temperatures. Normal conditions at some studied sites could be considered as stressing in other geographical areas.

Our experiments showed that the shrimp $P$. argenti$n u s$, the amphipod $H$. curvispina and the macrophyte $E$. densa, when transplanted to polluted areas have a decreased survivorship (invertebrates) or a reduced growth (macrophyte). Those species can be considered sensitive and, therefore, be used in in situ assays aiming to assess the biological quality of water. Moreover, the results of the tests were consistent with the chemical changes in the water, and with the biological status, as judged by changes in the diatom and macroinvertebrate assemblages, and the application of biotic indices.

Biotic indices classified the reference sites as presumably slightly polluted by organic enrichment. This result may reflect (a) diffuse nutrient enrichment derived from human activities of the La Pampa area or (b) natural enrichment. Whatever may be the case, the application of in situ tests were useful to quantify the deterioration of biological condition due to the discharge of polluted waters. 


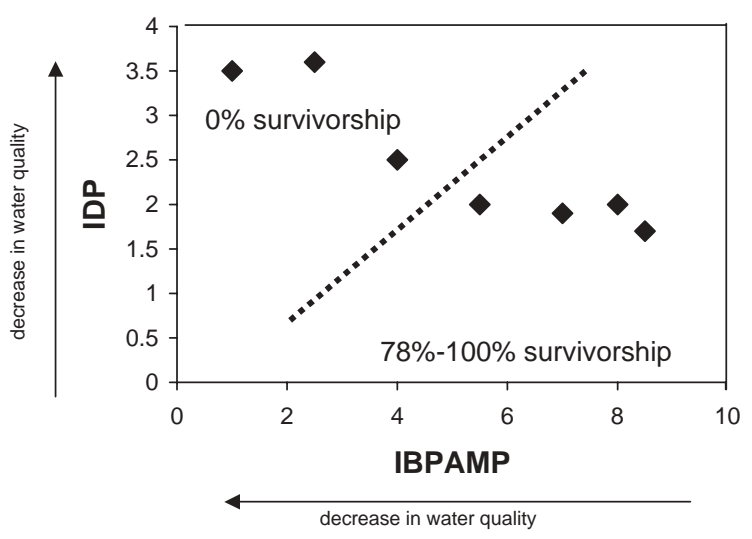

Fig. 4. By plot of sampling sites according with their biological classification using the biotic indices IBPAMP (macroinvertebrates) and IDP (algae) and the overall survivorship of the amphipod $H$. curvispina and the shrimp $P$. argentinus. No IDP data was available for the impacted site "Pescado". The dotted line separates reference from impacted sites.

Moreover, the in situ tests were sensitive to the pollution whereas the laboratory tests were not. Consistently, other authors have reported higher sensitivity with in situ tests when compared with laboratory assays e.g. [6]. The reason for the high survival of invertebrates under laboratory conditions was not investigated but it may be related to the "in stream" decreases in the oxygen levels during the diurnal cycle, loss of volatile compounds under laboratory conditions, etc.

In general, laboratory tests are run under standardized environmental conditions. Additionally, laboratory tests minimize physiological differences among testing organisms. In contrast to those assays, the results of in situ test may be affected by the physiological condition of organisms e.g. [8]. However, the incorporation of this natural variability and the natural variability of environmental conditions such as current, diel changes in temperature, oxygen, light conditions, and others affecting the aquatic biota address the criticism of the lack of realism of the traditional laboratory tests e.g. [23]. In a field experiment in which farm waste episodes were simulated [8], reported that increased ammonia or decreased oxygen were not enough to cause significant mortality in several macroinvertebrates. However, the combination of low oxygen and high ammonia caused high mortality. Under eutrophic conditions, oxygen content in water is one of the factors fluctuating during the day/night cycle.

Salazar and Salazar [24] showed that pulp and paper mills discharges affected the growth of caged bivalves and proposed that they could be used as a biomonitoring tool, see also [25]. Caged animals and plants can also be used in a longer time exposures to assess bioaccumulation of toxicants $[24,26]$ or to measure other sublethal effects of pollutants such as changes in feeding rates, "scope for growth" and disruption of pre-copula pairs of the amphipod Gammarus pulex [2,8,27].

In situ assays are not limited to measurements at individual levels. Transplantation of periphytic assemblages from clean to polluted areas in river systems around La Plata, Argentina, also resulted sensitive tools to evaluate the deterioration of environmental conditions [22].

Another issue addressed by in situ tests is the use of native species. Non-native species may not occur in the environments where the toxicants are discharged [28]. Standard species are generally selected based on their absolute sensitivity, regardless of the natural conditions. Fish and invertebrates in the Argentinean Pampa are tolerant to eutrophic conditions naturally prevalent on the local rivers. For instance, $H$. curvispina is one of the sensitive taxa in the area, as judged by their rapid disappearance from polluted sites [15]. However, this species is found in river sections where the oxygen content may drop to $6 \mathrm{mg} \mathrm{L}^{-1}$, and tolerate high conductivity $\left(\sim 780 \mu \mathrm{S} \mathrm{cm}^{-2}\right), \mathrm{BOD}_{5}$ and COD (respectively, $\sim 7$ and $\left.36 \mathrm{mg} \mathrm{O}_{2} \mathrm{~L}^{-1}\right)$ phosphates and ammonia ( $\sim 0.35 \mathrm{mg} \mathrm{L}^{-1}$; [15]). These conditions may be unfavourable for many organisms commonly used in toxicity tests. The stream communities at the Pampean rivers and streams are, therefore, potentially more resistant to a slight increase in nutrients and the results from toxicity tests with invertebrates originated from oligotrophic conditions may be questionable to assess the conditions in the Pampas.

Amphipods in other areas are also regarded as sensitive organisms. The European Gammarus pulex L. is replaced by the isopod Asellus aquaticus L. as dominant species in situations of organic pollution [29]. For this reason, Whitehurst [30] proposed the use of Gammarus: Asellus ratio as an indicator of stressing conditions. The North American conspecific Hyalella azteca is a common test organism used in ecotoxicological assays e.g. [31].

$P$. argentinus was previously shown to be a sensitive species to toxicants [13]. The conspecific marine $P$. pugio has also been used in toxicity assays [32].

Finally, aquatic plants are less used in toxicity assays. Our results suggest that they may also be used to assess sub-lethal effects of perturbations, in agreement with the reported references for a decreased plant growth in terms of mass and length, and a reduced root development with an increased pollution stress under laboratory conditions, e.g. [33].

Given that there is not a single method capable of integrating the complex changes caused by pollution discharges and given that different methods address different questions, whenever possible, an integrated 
approach should be used when assessing the effects of pollution discharges. An integrated assessment gathers complementary lines of evidence of an ecological effect/ ecological integrity of a system. We conclude that, given the realistic nature of the in situ tests, they should be considered in this strategy.

\section{Acknowledgements}

This project was financed by the Grant 01-0000001812 (FONCYT) and the Consejo Nacional de Investigaciones Científicas y Técnicas (CONICET) No. 4740 .

\section{References}

[1] Metcalfe-Smith, JL. Biological water-quality assessment of rivers: use of macroinvertebrate communities. In: Calow $\mathrm{P}$, Petts GE, editors. The rivers handbook, vol. 144-170. Oxford: Blackwell Science, 1996. 526pp.

[2] Naylor C, Maltby L, Calow P. Scope for growth in Gammarus pulex, a freshwater benthic detritivore. Hydrobiologia 1989;188/189:517-23.

[3] Klemm DJ, Lobring LB, Horning WH. Manual for the evaluation of laboratories performing aquatic toxicity tests. Cincinnati, Ohio, 1991.

[4] Pontasch KW, Cairns J. Multispecies toxicity test using indigenous organisms: predicting the effects of complex effluents in streams. Arch Environ Contam Toxicol 1991;20:103-12.

[5] Lowell RB, Culp JM, Wrona FJ. Stimulation of increased short-term growth and development of mayflies by pulp mill effluent. Environ Toxicol Chem 1995;14:1529-41.

[6] Sasson-Brickson G, Burton JGA. In situ laboratory sediment toxicity testing with Ceratodaphnia dubia. Environ Toxicol Chem 1991;10:201-7.

[7] Edwards RW, Ormerod SJ, Turner C. Field experiments to assess biological effects of pollution episodes in streams. Verh Internat Verein Limnol 1991;24:1734-7.

[8] McCahon CP, Poulton MJ, Thomas PC, Xu Q, Pascoe D, Turner C. Lethal and sub-lethal toxicity of field simulated farm waste episodes to several freshwater invertebrate species. Water Res 1991;25:661-71.

[9] Salazar MH, Salazar SM. Using caged bivalves for environmental effects monitoring at pulp and paper mills: rationale and historical perspective. Proceedings of the 23rd Aquatic Toxicity Workshop: Tools for Ecological Risk Assessment, Calgary, Alta., Canada, 1996. p. 129-36.

[10] Rodrigues Capítulo A, Freyre LR. Metabolismo energético del camarón de agua dulce Palaemonetes argentinus Nobili de la laguna de Chascomús (Decapoda Natantia). Limnobios 1979;1:337-45.

[11] Rodrigues Capítulo A, Freyre LR. Demografía de Palaemonetes (P.) argentinus Nobili. (Decapoda Natantia). I. Crecimiento. Limnobios 1988;2:32-44.

[12] Rodrigues Capítulo A, Freyre LR. Demografía de Palaemonetes (P.) argentinus Nobili (Decapoda Natantia).
II. Supervivencia, migraciones, biomasa y fecundidad. Limnetica 1997;11:39-47.

[13] Rodrigues Capítulo A. Efecto de los detergentes aniónicos sobre la supervivencia y tasa de metabolismo energético de Palaemonetes argentinus Nobili (Decapoda Natantia). Limnobios 1984;2:549-55.

[14] Rodrigues Capítulo A. Los macroinvertebrados como indicadores de la calidad de ambientes lóticos en el área pampeana. Rev Soc Entomol Argent 1999;58:208-17.

[15] Rodrigues Capítulo A, Tangorra M, Ocón C. Use of Benthic macroinvertebrate to assess the ecological status of pampean rivers (Argentine). Aquat Ecol 2001;35:109-19.

[16] Wardlaw AC. Practical statistics for experimental biologists. Chichester: Wiley, 1989. 290pp.

[17] Stevenson RJ. Epilithic and epipelic diatoms in the Sandusky River, with emphasis on species diversity and water pollution. Hydrobiologia 1984;114:114-61.

[18] Lowe R, Laliberte GD. Benthic stream algae: distribution and structure. In: Hauer R, Lamberti GA, editors. Stream ecology. New York: Academic Press, 1996. 669pp.

[19] Gómez N, Licursi M. The Pampean Diatom Index (IDP) for assessment of rivers and streams in Argentina. Aquat Ecol 2001;35:173-81.

[20] Strickland JDH, Parsons TR. A practical handbook for seawater analysis, 2nd ed. Bull Fish Res Bd Ottawa, Canada. 1972, 167pp.

[21] Mackereth FJH, Heron J, Talling JF. Water analysis: some revised methods for limnologists. Freshwater Biological Association, Scientific Publication No. 36, 1978.

[22] Tolcach ER, Gómez N. Translocation of microbenthic communities in a polluted lowland stream. Verh Internat Verein Limnol, in press.

[23] Cairns J. Are single species tests alone adequate for estimating hazard? Hydrobiologia 1983;100:47-57.

[24] Salazar MH, Salazar SM. Using caged bivalves to characterize exposure and effects associated with pulp and paper mill effluents. Water Sci Technol 1996;35: 213-20.

[25] Smith JG, Beauchamp JJ. Evaluation of caging designs and a fingernail clam for use in an in situ bioassay. Environ Monitor Assess 2000;62:205-30.

[26] Nelson SM, Campbell SG. Integrated assessment of metals contamination in a lotic system using water chemistry, transplanted bryophytes and macroinvertebrates. J Freshwat Ecol 1995;10:409-20.

[27] Forrow DM, Maltby L. Toward a mechanistic understanding of contaminated-induced changes in detritus processing in streams: direct and indirect effects on detritivore feeding. Environ Toxicol Chem 2000;19: 2100-6.

[28] Stewart PM. Use of algae in aquatic pollution assessment. Nat Areas J 1995;15:234-9.

[29] Graça MAS, Maltby L, Calow P. Comparative ecology of Gammarus pulex (L.) and Asellus aquaticus (L.) I: population dynamics and microdistribution. Hydrobiologia 1994;281:155-62.

[30] Whitehurst I. The Gammarus: Asellus ratio as an index of organic pollution. Water Res 1991;25:333-9.

[31] Borgmann U, Bothwell ML. Chronic toxicity of ammonia to the amphipod Hyalella azteca; importance of ammonium ion and water hardness Eutrophication of rivers by 
nutrients in treated kraft pulp mill effluent. Environ Pollut 1994;86:329-35.

[32] Lewis MA, Foss SS. A caridean grass shrimp (Palaemonetes pugio Holthius) as an indicator of sediment quality in Florida coastal areas affected by point and nonpoint source contamination. Environ Toxicol 2000;15:234-424.
[33] Roshon, RD, Stephenson GR. Comparison of two reference toxicants and their effect upon the growth and development of Myriophyllum sibiricum in axenic culture, In: Little EE, De Lonay AJ, Greenberg BM, editors. ASTM, Environmental toxicology and risk assessment. p. 200-13. 